\title{
Kinetics of early in vitro development of bovine in vivo- and in vitro-derived zygotes produced and/or cultured in chemically defined or serum-containing media
}

\author{
P. Holm, P. J. Booth and H. Callesen* \\ Department of Animal Breeding and Genetics, Danish Institute of Agricultural Sciences, \\ PO Box 50, DK-8830 Tjele, Denmark
}

The kinetics of the in vitro development of early embryos from bovine zygotes derived in vitro and in vitro were compared, investigating the effect of serum during in vitro maturation and fertilization (IVM-IVF) and in culture. Zygotes were collected from superovulated heifers or produced in vitro from immature oocytes with or without serum supplementation, and cultured subsequently in defined culture medium (SOFaaci) with or without serum supplementation. Time-lapse images were recorded every $0.5 \mathrm{~h}$ throughout the culture period. More in vivo- than in vitro-derived zygotes developed to the compact morula or blastocyst stages $(87 \%$ versus $47-54 \%$, respectively; $P<0.05)$. Embryo development was blocked predominantly at the second or fourth cell cycles ( 28 and $29 \%$ ). However, blastomeres degenerated at all cleavage stages. Serum supplementation during IVM-IVF resulted in abnor-

\section{Introduction}

It is generally accepted that bovine embryos produced in vitro have a lower developmental capacity than do embryos produced in vivo. Large field trials under commercial conditions have shown that pregnancy rates after transfer of both frozen-thawed and fresh in vitro-produced embryos are generally reduced significantly (Hasler et al., 1995; Galli and Lazzari, 1996; Merton, 1997; van Wagtendonkde Leeuw et al., 2000). Furthermore, studies of, for example, embryo morphology, metabolism, chromosome configuration and gene expression have pinpointed specific dissimilarities between in vivo- and in vitro-produced embryos (for reviews, see van Soom and de Kruif, 1992; Thompson, 1997; Holm and Callesen, 1998).

Production of bovine embryos in vitro is generally referred to as a three-step procedure, namely oocyte maturation, fertilization (including in vitro sperm preparation) and culture of the in vitro-derived zygote. Deviations compared with in vivo-derived embryos may originate from any of these steps. Embryo culture conditions can influence in vitro embryo development significantly. This is exemplified

*Correspondence

Email: henrik.callesen@agrsci.dk mally sized blastomeres at first cleavage (defined serum: $20-22 \%$ versus in vivo-derived: $8 \%, P<0.05)$. The duration of the second, third and fifth cell cycles of in vivoderived zygotes were $1-5 \mathrm{~h}$ shorter compared with those of in vitro-derived zygotes cultured under similar conditions $(P<0.05)$. However, the kinetics of embryo development was affected by serum during IVM-IVF and culture. The first and fourth cell cycles were prolonged by $4-5 \mathrm{~h}$ in the absence of serum during IVM-IVF, whereas the presence of serum during culture decreased the duration of the fourth cell cycle and triggered premature blastulation. The results of this study illustrate the differences and similarities between the morphology and developmental kinetics of in vivo- and in vitro-derived zygotes, and show how serum supplementation during IVM-IVF and culture can alter these parameters.

by the general improvement of bovine in vitro embryo production systems that has taken place, which has resulted in blastocyst developmental rates of $40-50 \%$ from inseminated oocytes in both routine experimental and commercial settings (Holm et al., 1999; Marquant-Le Guienne et al., 2001; Watanabe et al., 2001). In particular, serum supplementation of the in vitro culture medium alters both embryo morphology and kinetics (Gardner, 1994; Pinyopummintr and Bavister, 1994; van Langendonckt et al., 1997; Yoshioka et al., 1997), but other factors may also influence the kinetics of embryo development directly (for example, growth factors: Yoshioka et al., 2000) or in more complex ways (for example, glucose and sex: Peippo et al., 2001). In sheep, in vitro maturation and fertilization (IVM-IVF) of oocytes compromises subsequent development of the zygotes compared with in vivo-matured and fertilized zygotes (Holm et al., 1996). Likewise, in vivo-derived bovine zygotes have a higher in vitro developmental capacity than do in vitroderived zygotes (van Soom and de Kruif, 1992; van de Leemput et al., 1999). These results illustrate the importance and influence of maturation and fertilization processes on the developmental capacity of the zygote.

The aim of the present study was to investigate: (i) the influence of in vivo versus in vitro maturation and fertilization on the in vitro developmental kinetics of the resulting 
Table 1. Experimental design

\begin{tabular}{|c|c|c|c|c|}
\hline \multirow[b]{2}{*}{ Experimental group } & \multirow[b]{2}{*}{ In vivo } & \multicolumn{3}{|c|}{ In vitro } \\
\hline & & Defined IVC & Defined IVP & Standard IVP \\
\hline Maturation & In vivo & IVM medium with serum & IVM medium (no serum or BSA) & IVM medium with serum \\
\hline Fertilization & Artificial insemination & IVF medium with serum & IVF medium (no serum or BSA) & IVF medium with serum \\
\hline Culture & IVC medium with PVA & IVC medium with PVA & IVC medium with PVA & IVC medium with serum \\
\hline $\begin{array}{l}\text { Number of trials } \\
\text { (number of cows) }\end{array}$ & $4(16)$ & 4 & $3 *$ & 4 \\
\hline
\end{tabular}

IVP: in vitro production; IVM (in vitro maturation) medium: bicarbonate-buffered medium 199 with hCG and eCG; IVF (in vitro fertilization) medium: modified Tyrode's medium without glucose and BSA; IVC (in vitro culture) medium: modified SOF with amino acids, myo-inositol and sodium citrate; PVA: polyvinylalcohol.

*One trial was excluded from the data as a result of technical failure in the time-lapse recording.

zygotes; and (ii) to compare the effect of presence versus absence of serum (and serum proteins) during (a) IVM-IVF and (b) embryo culture conditions on subsequent kinetics of development of in vitro-derived zygotes.

\section{Materials and Methods}

In vivo-derived zygotes

A total of 15 Danish Holstein-Friesian heifers (1-5 per trial) were synchronized with $500 \mu$ g cloprostenol (Estrumate ${ }^{\circledR}$ vet.; Schering-Plough, Farum) and superovulated in the following oestrous cycle with $200 \mathrm{mg}$ NIH-FSH-P1 (Folltropin ${ }^{\circledR}-\mathrm{V}$; Vetrepharm, Bellesville) administered over 4 days in decreasing doses. Oestrus was induced by two injections of $375 \mu \mathrm{g}$ cloprostenol, administered morning and evening on day 3 of FSH treatment, and the heifers were subsequently inseminated twice and killed, approximately 48 and 56 h, and $72-75 \mathrm{~h}$, respectively, after the first cloprostenol injection. Within $30 \mathrm{~min}$ after death, the genital tracts were transported to the laboratory and both oviducts were flushed twice with $20 \mathrm{ml}$ Hepes-buffered medium 199 (Sigma, St Louis, MO) supplemented with $3 \mathrm{mg}$ polyvinylalcohol $\mathrm{ml}^{-1}$ (PVA; Sigma). The in vivo-derived zygotes were recovered, washed three times and transferred to the time-lapse culture system (Holm et al., 1998) in a chemically defined synthetic oviduct fluid (SOF) medium supplemented with amino acids (30 $\mu$ l basal medium Eagle (BME) $\mathrm{ml}^{-1}$ and $10 \mu \mathrm{l}$ minimal essential medium (MEM) $\mathrm{ml}^{-1}$; Sigma), $2.8 \mathrm{mmol}$ myo-inositol $\mathrm{I}^{-1}$ (Sigma) and 0.3 mmol sodium citrate $\mathrm{I}^{-1}$ (Sigma) (Holm et al., 1999; SOFaaci medium). The genital tracts, flushing medium and zygotes were kept at $30-35^{\circ} \mathrm{C}$ during handling.

\section{In vitro-derived zygotes}

Immature oocytes were aspirated from 2-8 $\mathrm{mm}$ follicles of ovaries obtained from an abattoir. In vitro maturation (IVM), sperm preparation and in vitro fertilization (IVF) were performed as described by Holm et al. (1999). In brief, immature bovine cumulus-oocyte complexes (COCs) were collected from the ovaries and matured for $24 \mathrm{~h}$ in IVM medium (bicarbonate-buffered M199 (Sigma) supplemented

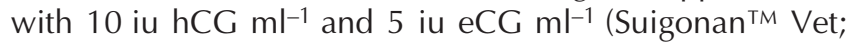
Intervet Scandinavia, Skovlunde)) in the presence or absence of $15 \%(\mathrm{v} / \mathrm{v})$ cattle serum (Danish Veterinary Laboratory, Frederiksberg) at $38.5^{\circ} \mathrm{C}$ in $5 \% \mathrm{CO}_{2}$ in humidified air.

IVF was performed in medium consisting of modified Tyrode's solution without glucose and BSA, but supplemented with 5 iu heparin $\mathrm{ml}^{-1}$ (Sigma), penicillamine (30 $\mathrm{mol} \mathrm{I}^{-1}$; Sigma), hypotaurine $\left(15 \mu \mathrm{mol} \mathrm{I}^{-1}\right.$; Sigma) and adrenaline $\left(1 \mu \mathrm{mol} \mathrm{I} \mathrm{I}^{-1}\right.$; Sigma). After maturation, the oocytes were inseminated with $2 \times 10^{6}$ Percoll-separated spermatozoa $\mathrm{ml}^{-1}$ (Percoll ${ }^{\circledR}$; Pharmacia AB, Uppsala) and the gametes were co-cultured for $20 \mathrm{~h}$ at $38.5^{\circ} \mathrm{C}$ in $5 \% \mathrm{CO}_{2}$ in humidified air. For oocytes matured in the presence of serum, the IVF medium was supplemented with approximately $1 \%(\mathrm{v} / \mathrm{v})$ cattle serum.

Semen from the same bull of proven IVF ability was used in all trials. The basic sperm preparation medium was defined modified Tyrode's solution without serum or BSA supplementation. After $20 \mathrm{~h}$ of gamete co-incubation for IVF, the putative zygotes were denuded by vortexing $(1 \mathrm{~min}$ at 2500 r.p.m.) and washed three times in Hepes-buffered M199 with 3 mg PVA ml-1 before transfer to the time-lapse system.

\section{In vitro culture and time-lapse recording}

In each trial, four groups of zygotes (10-40 in each group) were cultured in a four-well culture dish $\left(\mathrm{Nunc}^{\circledR}\right.$, Roskilde) until the blastocyst stage in $400 \mu \mathrm{l}$ in vitro culture medium (SOFaaci supplemented with either $3 \mathrm{mg} \mathrm{PVA} \mathrm{ml}^{-1}$ or $5 \%(\mathrm{v} / \mathrm{v})$ cattle serum) under oil (Uvasol ${ }^{\circledR}$; Merck KGaA, Darmstadt) in an atmosphere of $5 \% \mathrm{O}_{2}, 5 \% \mathrm{CO}_{2}$ and $90 \%$ $\mathrm{N}_{2}$ (Holm et al., 1999; see Table 1 for experimental design).

The time-lapse incubator system was as described by Holm et al. (1998). In brief, each four-well culture dish was placed on the microscope stage (MultiControl 2000 Scanning stage; Märzhäuser, Pulheim) of an inverted Nikon TMD microscope (Diaphot; DFA A/S, Copenhagen). A black plexiglas incubator box regulated by an air temperature controller (Air-Therm ${ }^{\mathrm{TM}}$; World Precision Instruments, Aston) was fitted around the stage. A small in vitro culture 


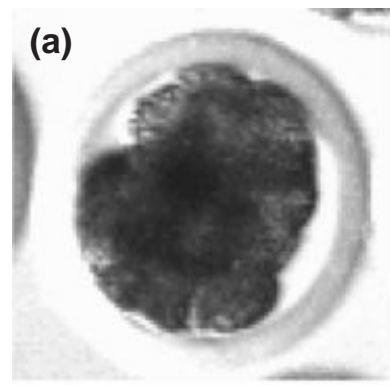

$122 \mathrm{~h}$

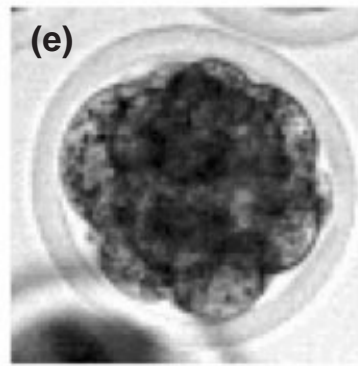

$115 \mathrm{~h}$

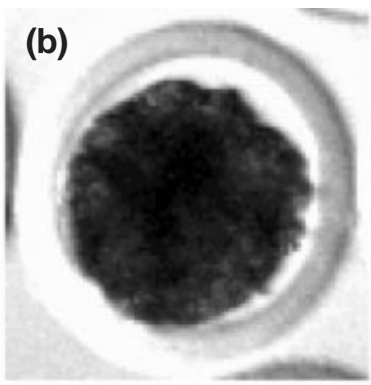

$135 \mathrm{~h}$

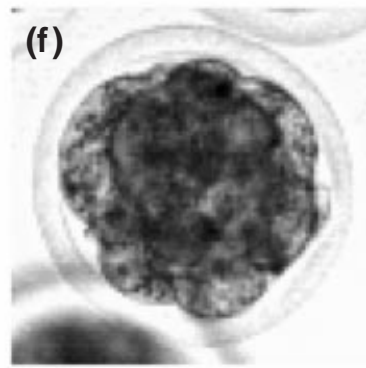

$123 \mathrm{~h}$

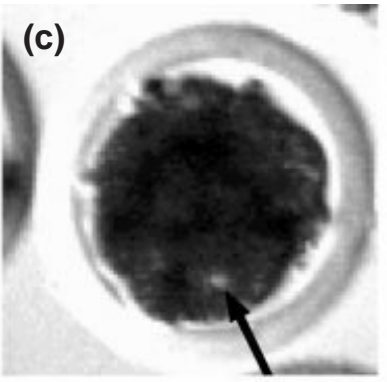

$136 \mathrm{~h}$

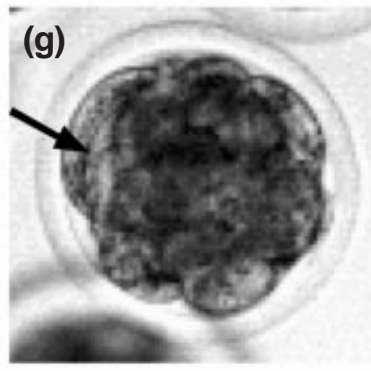

$124 \mathrm{~h}$

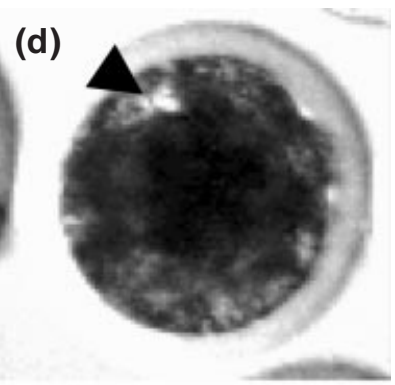

$145 \mathrm{~h}$

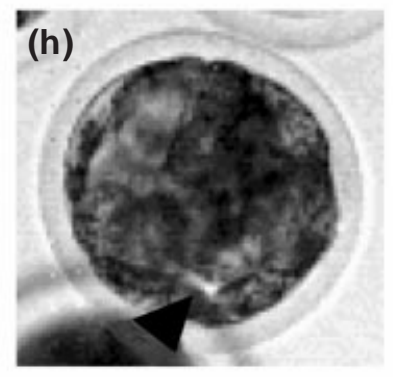

$130 \mathrm{~h}$

Fig. 1. Compaction and early blastulation in in vitro-produced bovine embryos cultured in (a-d) defined, serum-free SOFaaci medium and (e-h) standard serum-supplemented SOFaaci medium. Note the lack of proper compaction and premature blastulation in (e-h). Times are hours from insemination to the time that the micrograph was taken. Arrows point at first observed intracellular fluid accumulation. Arrowheads point at first observed stable confluent blastocoel.

chamber with a glass top and open bottom was placed over the culture dish and the humidified gas mixture was led into this culture chamber after passing through a gas washing bottle placed inside the incubator box. The timelapse recording was directed by Image Analysis software (MicroVision ${ }^{\mathrm{TM}}$; Image House $\mathrm{A} / \mathrm{S}$, Copenhagen), which controlled both the movements of the scanning stage in the $x, y$ and $z$ axes, the operation of the connected highly light sensitive video camera (CF 8/1 DXC; Kappa, Gleichen), and the recording and storage of time-lapse sequences on the computer hard disc.

Images of each group (total magnification: $\times 265$ ) were recorded sequentially in minimal light at intervals of $30 \mathrm{~min}$ throughout culture. The embryos were moved out of the light field between recordings.

Our weekly routine in vitro embryo production during the experimental period (Holm et al., 1999) served as a control for the integrity of the basic culture system.

\section{Experimental design, definitions and data analysis}

The experimental design is shown (Table 1). Only zygotes that could be identified individually during the entire culture period were included in the analysis. Moreover, a variable proportion of zygotes had to be eliminated from the data set at the respective cleavage events owing to temporary movements out of the focal plane, blurring of the viable blastomeres of identified embryos or to temporary technical problems with the image recording or storage. Blurring of blastomeres was caused by covering zygotes, cellular debris or other degenerated blastomeres.

Zygotes that developed to the compact morula or blastocyst stages within 7 days after insemination were regarded and designated as viable. In contrast, zygotes that did not reach these stages by that time were regarded as degenerated or retarded and designated as non-viable.

The time of the first appearance of the following cleavage or embryo stages was recorded for zygotes in focus with identifiable blastomeres: two-, three- to four-, five-, eight-, nine- and 16-cell stages; and for morulae and blastocysts with a visible coherent cell mass: early morula, compact morula, early blastocyst, expanded blastocyst and hatching blastocyst stages (Fig. 1). If proper evaluation of specific cleavage events was not possible (see above), the particular data points were treated as missing data.

The cleavage stages of embryos in which one or more blastomeres stopped further cleavage were categorized according to the number of cell cycles observed in the healthy blastomeres; for example, an embryo with three healthy, cleaving blastomeres and one arrested blastomere would be characterized as a five- to eight-cell stage embryo. From the fourth cell cycle onwards, not every individual blastomere could be observed directly. However, the passing from the fourth and fifth cell cycles, respectively, to the following 
cycles was defined by combining the direct chronological observation of cleaving blastomeres or initiation of intensive movements within the cell mass created by blastomere cleavage, the cessation of all cleavages and movements followed by a resting period (presumably during the S-phase of the cell cycle), and then the start of a new cleavage round creating new movements. An embryo was defined to have reached the early morula stage when first signs of compaction could be observed, but with blastomeres still clearly distinguishable on the surface (an appearance that has been referred to as a 'cell ball' of small blastomeres; Lindner and Wright, 1983; see also Fig. 1). The compact morula was defined as the stage at which blastomeres had coalesced to form a smooth, tightly compacted cell mass with minimal diameter (Fig. 1). The appearance of the early blastocyst stage was characterized by the first appearance of a stable confluent blastocoel. Blastocysts were characterized as expanded when the diameter of the zona pellucida was increased as a result of expansion of the blastocoel. Finally, expanded blastocysts were identified as hatching when their zona pellucida cracked.

Abnormal cleavages leading to different sized or unequal numbers of blastomeres were recorded. Blastomere degeneration or exclusion of blastomeres from the cell mass of morulae resulting in embryos of reduced size (one-half, two-third or three-quarter embryos) was also recorded.

In one trial, observed reductions in blastocyst diameter (as a result of partial or total collapse of the blastocoel) were recorded, and the diameter and area of compact morulae and the diameter of expanded blastocysts at maximum expansion immediately before hatching were measured using the measuring features of the image analysis software.

The duration of the cell cycle and time intervals from the two-cell to subsequent stages were compared to provide a comparison between the cleavage events of in vivo- and in vitro-derived zygotes. The duration of the cell cycle and the time interval from insemination to subsequent cleavage stages were compared for in vitro zygotes produced in the absence or presence of serum (see Table 1).

\section{Statistical analysis}

Time-lapse data were analysed by mixed linear model (SAS, 1992), using experimental group (see Table 1) and zygote category (viable versus non-viable) as independent parameters, and replicate (trial) as a random parameter. Possible statistical differences between individual treatment groups were compared on the basis of the respective least squared mean values calculated by the mixed procedure. Time intervals are given in $\mathrm{h}$ and are mean \pm SD unless otherwise noted. Cleavage and developmental data (for example, blastocyst rate, frequency of abnormal cleavages) were analysed by a generalized linear model (logistic regression of binomial distributed proportions; SAS, 1993) using experimental group, replicate and zygote category as independent parameters when appropriate. The level of significance was $P \leqslant 0.05$.

\section{Results}

In vitro development and cell death of viable and nonviable zygotes

In total, 452 zygotes were observed in the time-lapse culture system and distributed as follows between the four experimental groups: (i) 143 in vivo-derived zygotes cultured in defined serum-free conditions (in vivo group); (2) 94 in vitro-derived zygotes matured, fertilized and cultured in the presence of serum (standard in vitro production (IVP) group); (iii) 142 in vitro-derived zygotes matured and fertilized with serum, but cultured in defined serum-free conditions (defined in vitro culture (IVC) group); and (iv) 73 in vitro-derived zygotes matured, fertilized and cultured entirely in defined, serum-free conditions (defined IVP). These zygotes represented (average per trial) $84 \pm 10$, $77 \pm 5,80 \pm 10$ and $60 \pm 20 \%$, respectively, of the recovered in vivo ova or inseminated in vitro oocytes in culture.

A significantly higher proportion of in vivo-derived zygotes $(87 \pm 17 \%)$ developed to the compact morula or blastocyst stages compared with in vitro-derived zygotes (from $47 \pm 12 \%$ to $54 \pm 10 \%$ ).

In general, the non-viable embryos tended to develop at a slightly slower rate than did the viable embryos during most of the cell cycles studied (Fig. 2) and the duration of the first, second and third cell cycles of non-viable zygotes were prolonged significantly (Fig. 3). There was a significant interaction between experimental group and viability at the fourth cell cycle, as in vivo-derived non-viable embryos took a longer time and in vitro-derived non-viable embryos took a shorter time to complete this cell cycle than did their viable counterparts.

No significant influence of treatments on the kinetics of embryo attrition was detected in the present study, so the data were pooled. The highest rates of attrition were observed in the second and fourth cell cycles $(P<0.001)$. Overall, development of $29 \pm 6,10 \pm 8,28 \pm 5,11 \pm 5$ and $11 \pm 15 \%$ of the 164 non-viable zygotes was blocked at the second, third, fourth, fifth and sixth cell cycles (at the early morula stage), respectively. In addition, $12 \pm 9 \%$ of these non-viable zygotes did not progress beyond the onecell stage, but degenerated after distinct cleavage attempts between approximately $20 \mathrm{~h}$ and $30 \mathrm{~h}$ after insemination. These one-cell zygotes, which were all produced in vitro and, thus, represented $16 \%$ of the non-viable in vitroderived zygotes, had been activated during fertilization, as intense activity was observed within their cytoplasm, leading to deformations or constrictions of the cell membranes but no cleavage. Similar behaviour was not observed for in vivo-produced one-cell ova.

Overall, $15 \%$ of all the zygotes included in the present study had an abnormal first cleavage; for example, cleavage into two cells of noticeably different sizes or directly into three or even four cells, often of irregular sizes. This abnormal first cleavage was observed in all treatment groups. However, the frequency of such abnormal cleavage was 


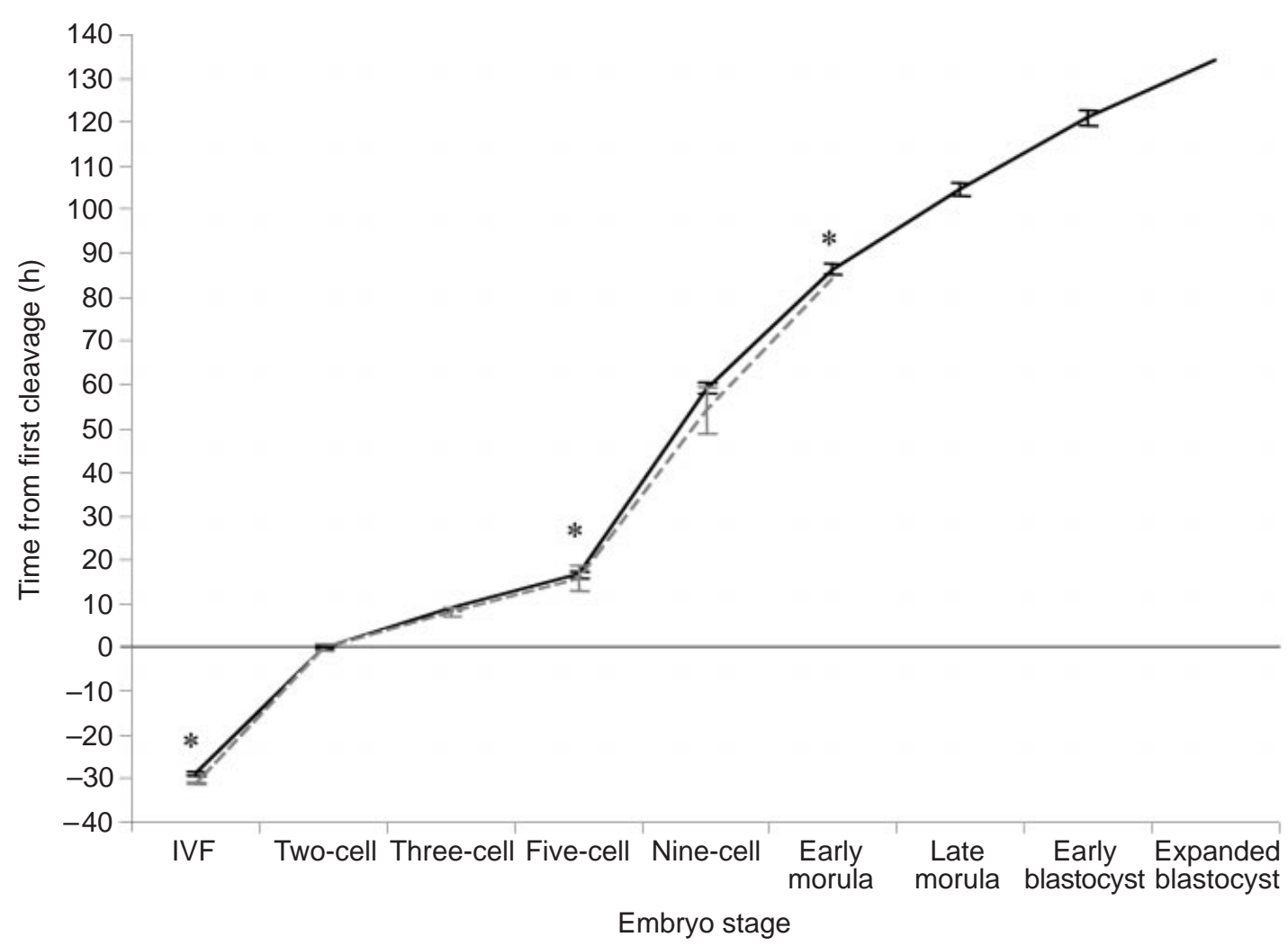

Fig. 2. Overall developmental kinetics of viable ( $n=281$; solid line) versus non-viable ( $n=165$; dashed line) in vitro- and in vivo-derived bovine zygotes cultured in vitro, shown as the average time interval \pm SD from the cleavage to two-cell embryo to the respective cleavage event. Means \pm SD are pooled across treatments. Embryos that developed to the late morulae or blastocyst stages within 7 days after insemination were defined as viable. IVF: in vitro-produced zygotes only. *Significant difference between zygote categories $(P \leqslant 0.05)$ by Mixed Procedure, SAS/STAT, model $y=$ treatment + viability + treatment $\times$ viability, random variable $=$ trial. There were no significant differences between treatments or interactions between treatment and viability.

influenced significantly by the presence of serum during maturation and fertilization $(8,22,21$ and $8 \%$ of the in vivo, standard IVP, defined IVC and defined IVP zygotes, respectively; $P<0.001)$. Furthermore, abnormal first cleavage was observed more frequently in non-viable than viable zygotes (across treatments: $22 \%(n=164)$ versus 10\% $(n=281)$, respectively; $P<0.001)$. None of the redundant cells was observed to cleave during the subsequent cell cycles.

Death of individual blastomeres was observed directly or indirectly at all precompaction stages in every treatment group. Overall, in $4 \%$ of all observed cell cycles (based on a total of 1193 cleavage observations) one or more blastomeres died (cleavage of specific blastomeres ceased). Subsequently, these blastomeres were often observed to disintegrate or fragment during a later cell cycle. The proportion of blastomere death varied significantly between the cell cycles with the highest frequency observed at the third cell cycle (Fig. 4). Neither treatment nor in vitro viability influenced this parameter significantly. As a consequence of this precompaction cell death, $13 \%$ of the total of 281 observed compact morulae had noticeably reduced size, varying from $8 \%$ to $14 \%$ between treatments (not significant). Cell death continued during compaction, frequently observed as exclusion of individual blastomeres from the compacted cell mass into the perivitelline space.

\section{Duration of cell cycles of viable zygotes}

The duration of the first cell cycle of in vivo-derived zygotes could not be measured, as the exact time of ovulation was unknown. For the in vitro-derived zygotes, the time from insemination to first cleavage was significantly longer for zygotes matured and fertilized in the absence of serum than in the other two in vitro groups $(31.7 \pm 0.5 \mathrm{~h}$ (defined IVP) versus $27.8 \pm 0.5 \mathrm{~h}$ (standard IVP) and $27.4 \pm 0.4 \mathrm{~h}$ (defined IVC); $P<0.01$ ). The duration of each of the subsequent cell cycles is shown (Table 2). The second and third cell cycles of in vivo-derived zygotes were about $1.5 \mathrm{~h}$ and just less than $1 \mathrm{~h}$, respectively, which are shorter than those of in vitro-derived zygotes (defined IVC and defined IVP groups; $P<0.01)$ cultured under defined conditions in the absence of serum. However, in the presence of serum during in vitro culture (standard IVP group), in vitro-derived zygotes tended to pass through the third cell cycle at a rate 


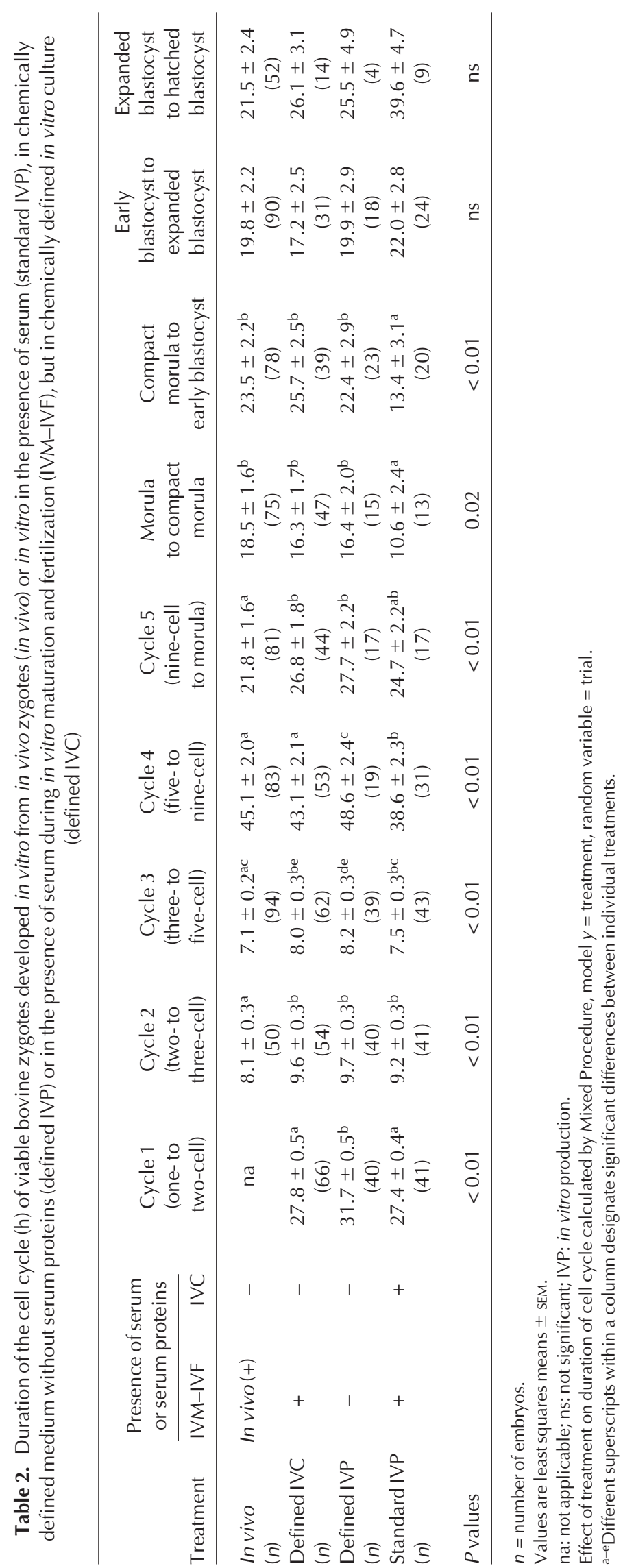




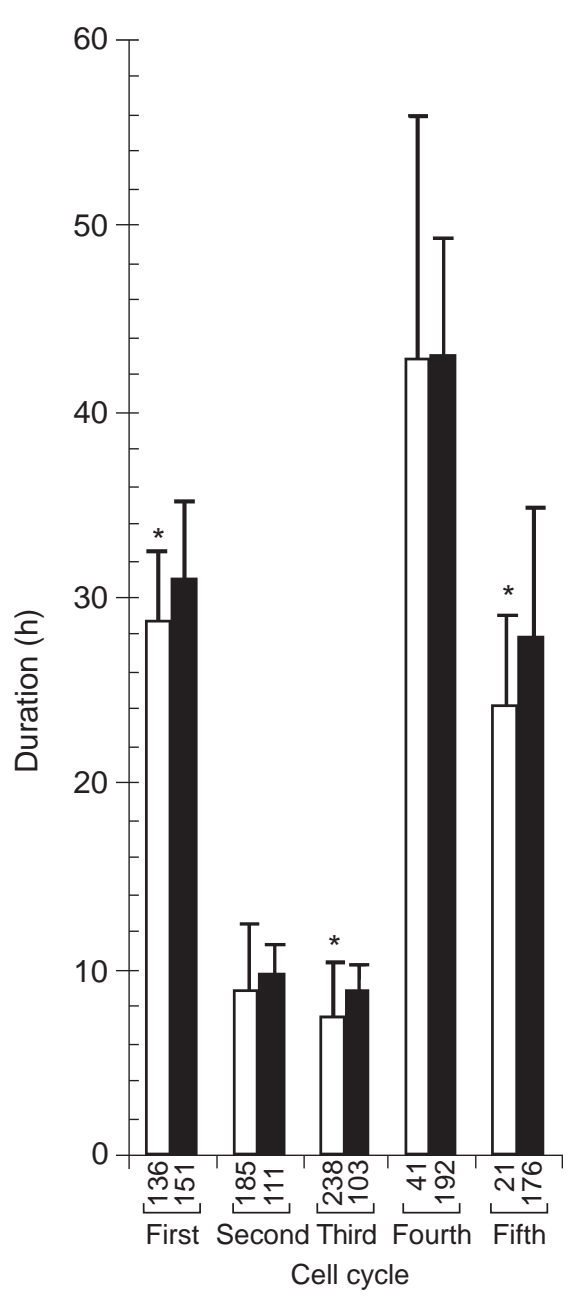

Fig. 3. Overall cell cycle duration of viable $(\square)$ versus non-viable $(\square)$ bovine zygotes cultured in vitro. Means \pm SD are calculated across treatments. *Significantly different from non-viable value $(P \leqslant 0.05)$ by Mixed Procedure, SAS/STAT, model $y=$ treatment + viability + treatment $\times$ viability, random variable $=$ trial. There were no significant differences between treatments or interactions between treatment and viability. Data for 'first' are for in vitroproduced zygotes only. Values are number of zygotes in each group.

in between those observed for in vivo- and in vitro-derived zygotes in the absence of serum. The fourth cell cycle was the longest cycle in all groups. It was observed to be 3.5-5.5 h longer in zygotes matured and fertilized in vitro in the absence of serum proteins (defined IVP) compared with both in vitro-derived zygotes matured and fertilized in the presence of serum (defined IVC) and in vivo-derived zygotes (in vivo group; $P<0.01$ ). Moreover, addition of serum to the culture medium (standard IVP) decreased the duration of the fourth cell cycle further by about $5 \mathrm{~h}$. The distribution of zygotes in relation to the duration of the fourth cell cycle is shown (Fig. 5).

The mean duration of the fifth cell cycle differed between in vivo- and in vitro-derived zygotes $(P<0.01)$ in a similar way to the variation observed in the second and third cell

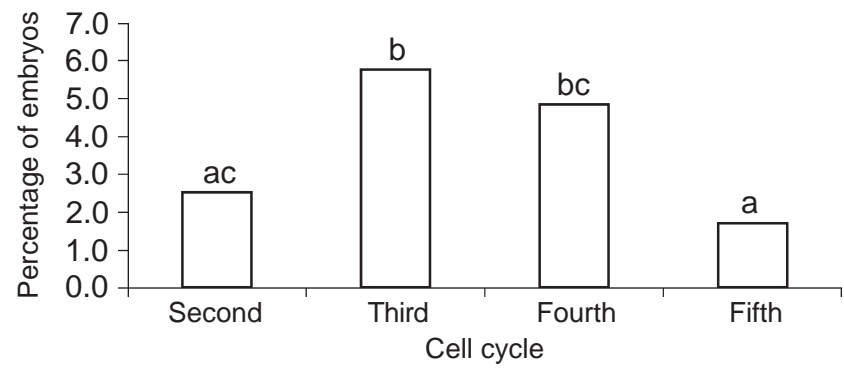

Fig. 4. Percentage of bovine embryos in second $(n=312)$, third $(n=344)$, fourth $(n=307)$ and fifth $(n=230)$ cell cycles in which blastomeres were dying. Frequencies are calculated across all treatment groups. ${ }^{a-c}$ Different letters indicate significant differences between columns $(P<0.05)$ by Genmod Procedure, SAS/STAT, model $y=$ treatment + cell cycle + treatment $\times$ cell cycle. There were no significant differences between treatments, but a significant interaction between treatment and cell cycle was observed.

cycles. In vivo-derived zygotes passed through the fifth cell cycle in the shortest time (a little less than $22 \mathrm{~h}$ and 5-6 h shorter than in vitro-derived zygotes (defined IVP and defined IVC) cultured similarly in the absence of serum. In the presence of serum, the duration of the cell cycle in in vitro-derived zygotes (standard IVP) was intermediate.

\section{Morula compaction and blastocyst expansion and hatching}

The shorter duration of the second, third and fifth cell cycles of in vivo-derived zygotes compared with the in vitro-derived zygotes cultured under similar defined conditions influenced their overall rate of development to the early morula and blastocyst stages (Table 3). Thus, in vivoderived two-cell zygotes $(n=33)$ reached the early morula stage after approximately $85 \mathrm{~h}$, which was 7 and $12 \mathrm{~h}$ earlier than in vitro-derived two-cell zygotes produced in the presence of serum (defined IVC) or in chemically defined medium (defined IVP), respectively $(P<0.05)$. In vitro-derived zygotes produced and cultured in the presence of serum (standard IVP) developed to the early morula stage at a similar rate, this being, on average, within $87 \mathrm{~h}$ from the two-cell stage. However, this was particularly a consequence of their short fourth cell cycle (Table 2).

Compaction and blastulation were not different between in vivo-derived zygotes and in vitro-derived zygotes cultured in chemically defined medium in the absence of serum (defined IVC and defined IVP): (i) the mean time intervals between the different morula and blastocyst stages did not differ (Table 2); (ii) the compact morulae of these zygotes appeared morphologically alike regarding tightness of compaction (Fig. 1); and (iii) the projected area of the cell mass at the compact morula stage was similar (see Table 4). In contrast, compaction and blastulation of in vitro-derived zygotes cultured in the presence of serum (standard IVP) were significantly different from the pattern described above. Firstly, the time interval from the early morula to the 


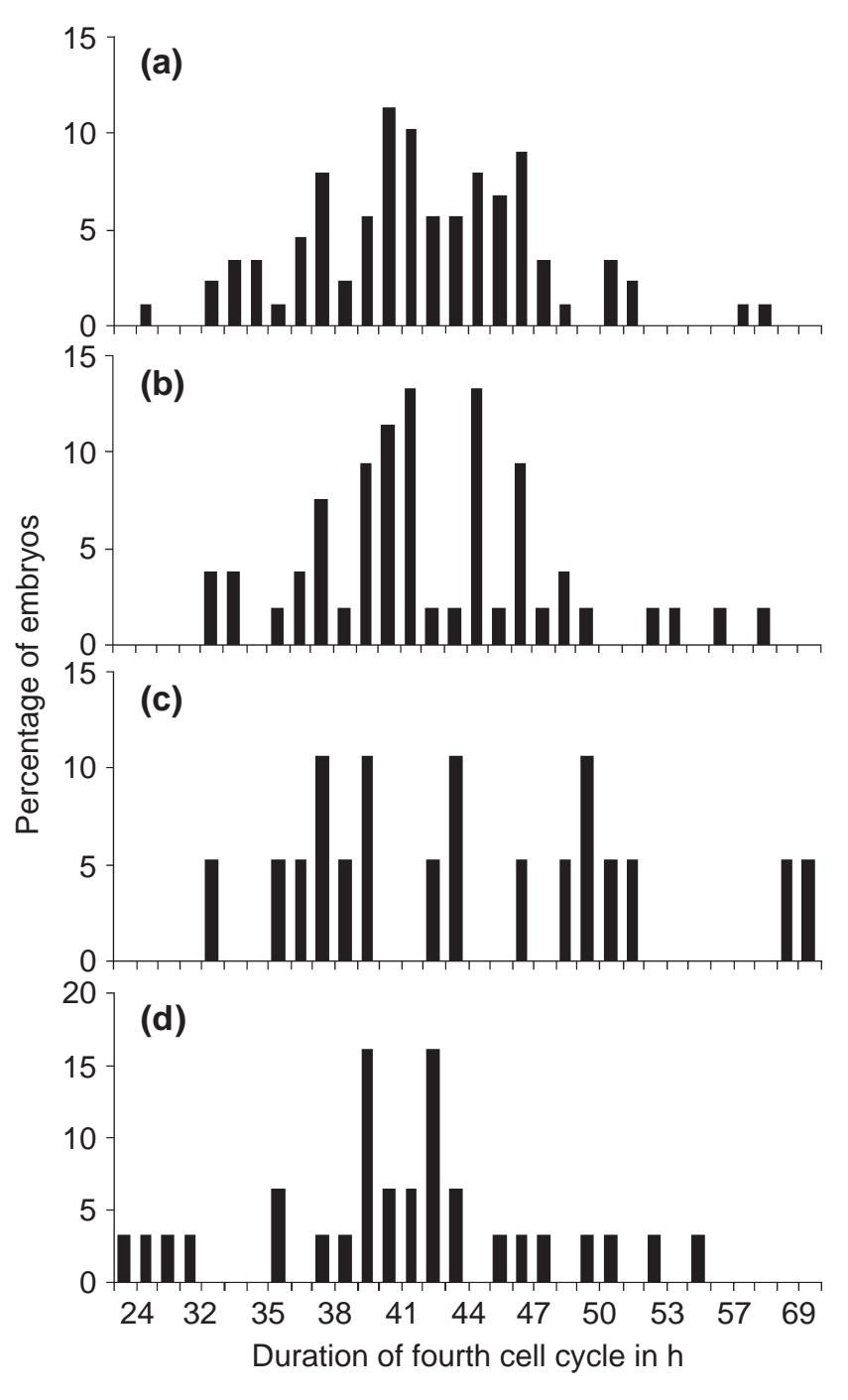

Fig. 5. Distribution of the duration of fourth cell cycle (h) for bovine embryos in each treatment group. (a) In vivo group $(n=88)$, in vivo-derived zygotes cultured in defined serum-free conditions; (b) defined in vitro culture (IVC) group $(n=52)$, in vitro-derived zygotes matured and fertilized with serum, but cultured in defined serum-free conditions; (c) defined in vitro production (IVP) group ( $n=18)$, in vitro-derived zygotes matured, fertilized and cultured in the presence of serum; and (iv) standard IVP group $(n=30)$, in vitro-derived zygotes matured, fertilized and cultured in the presence of serum.

compact morula with maximal compaction stage was about 6-8 $\mathrm{h}$ shorter (Table 2) in the presence of serum, and these zygotes did not compact to the same extent as did in vitroderived zygotes cultured in the absence of serum (Fig. 1). This was also illustrated by their 10\% larger cell mass area at the time of maximal compaction (Table 4). Secondly, blastulation had already occurred at $13 \mathrm{~h}$ after maximal compaction, which was 9-12 h earlier than in all the other zygotes cultured in the absence of serum (Table 2).

In all blastocysts, from the earliest to the hatched stages, expansion of the blastocoel in vitro occurred as irregular pulses of sudden partial or occasionally total collapses followed by further re-expansion. In the present study, blastocysts completed on average 6-10 pulses from the start of blastulation to the rupture of the zona pellucida (with a variation from one to $>20$ ). Blastocysts produced entirely in chemically defined media (defined IVP) underwent significantly more collapses than did blastocysts of the other groups (Table 4). A large proportion of expanded blastocysts experienced at least one total collapse, which often coincided with the rupture of the zona pellucida. The subsequent full re-expansion to the maximal diameter of about 200-220 $\mu \mathrm{m}$ (Table 4) was normally accomplished within 2.0-2.5 h.

The diameter of in vivo-derived blastocysts was significantly smaller at the time of zona pellucida rupture compared with that of in vitro-derived blastocysts from all treatment groups (Table 4).

\section{Discussion}

In the present study, time-lapse video analysis was used to describe and compare the developmental kinetics of in vivo- and in vitro-produced zygotes, and to investigate the influence of serum during IVM-IVF and culture on developmental kinetics of in vitro-derived zygotes. The experimental context of this study is of utmost importance for scientific interpretation and further possible generalization. Firstly, all the zygotes were subjected to in vitro conditions of variable duration and, thus, the behaviour of in vivoderived zygotes is a reflection of their origin rather than a mirror of the behaviour of similar embryos in vivo. Secondly, the kinetics of embryo development are the outcome of very complex interactive processes that are influenced by many factors, some of which are difficult to control or are not known. An example of this is the multifaceted interaction between glucose, embryo sex and time-lapse conditions that influence the kinetics of embryo development (Peippo et al., 2001).

As in other kinetic studies (Grisart et al., 1994; van Langendonckt et al., 1997; Holm et al., 1998), the timelapse culture system used in the present study supported embryo development in a similar way to incubator controls. These standard control cultures comprise IVM-IVF and culture of about 100 immature oocytes in serum-supplemented media equivalent to those used in the standard IVP treatment in the present study. Rates of cleavage and development to the blastocyst stage of the incubator controls varied during the experimental period between 75-90\% and $40-55 \%$, respectively (data not shown). Hence, embryo development was comparable to earlier published results regarding our SOF culture system (Holm et al., 1999).

Zygotes capable of developing beyond the early morula stage, thereby initiating the first blastomere differentiation, generally developed faster during the first three cell cycles than did the remaining zygotes. In the present study, this difference was about $1-2 \mathrm{~h}$. This relationship between the duration of the first cell cycle(s) and in vitro viability has 
Table 3. Intervals (h) from two-cell stage to different cleavage stages of viable bovine zygotes developed in vitro from in vivo zygotes (in vivo) or in vitro in the presence of serum (standard IVP), in chemically defined medium without serum proteins (defined IVP) or in the presence of serum during in vitro maturation and fertilization (IVM-IVF), but in chemically defined in vitro culture (defined IVC)

\begin{tabular}{|c|c|c|c|c|c|c|c|c|c|}
\hline \multirow[b]{2}{*}{ Treatment } & \multicolumn{2}{|c|}{$\begin{array}{l}\text { Presence of serum } \\
\text { or serum proteins }\end{array}$} & \multirow{2}{*}{$\begin{array}{l}\text { Three- to } \\
\text { four-cell }\end{array}$} & \multirow[b]{2}{*}{ Five-cell } & \multirow[b]{2}{*}{ Nine-cell } & \multirow[b]{2}{*}{ Morula } & \multirow{2}{*}{$\begin{array}{l}\text { Compact } \\
\text { morula }\end{array}$} & \multirow{2}{*}{$\begin{array}{c}\text { Early } \\
\text { blastocyst }\end{array}$} & \multirow{2}{*}{$\begin{array}{l}\text { Expanded } \\
\text { blastocyst* }\end{array}$} \\
\hline & IVM-IVF & IVC & & & & & & & \\
\hline $\begin{array}{l}\text { In vivo } \\
(n)\end{array}$ & In vivo $(+)$ & - & $\begin{array}{c}8.1 \pm 0.3^{a} \\
(50)\end{array}$ & $\begin{array}{c}15.4 \pm 0.5^{a} \\
(49)\end{array}$ & $\begin{array}{c}61.1 \pm 2.3^{a} \\
(39)\end{array}$ & $\begin{array}{c}85.1 \pm 4.8^{\mathrm{a}} \\
(33)\end{array}$ & $\begin{array}{c}104.0 \pm 3.2 b \\
(38)\end{array}$ & $\begin{array}{c}126.4 \pm 2.9^{b} \\
(44)\end{array}$ & $\begin{array}{c}142.4 \pm 3.9^{b} \\
(36)\end{array}$ \\
\hline $\begin{array}{l}\text { Defined IVC } \\
(n)\end{array}$ & + & - & $\begin{array}{c}9.6 \pm 03^{b} \\
(54)\end{array}$ & $\begin{array}{c}17.9 \pm 0.5^{b} \\
(54)\end{array}$ & $\begin{array}{c}60.7 \pm 2.2^{\mathrm{a}} \\
(47)\end{array}$ & $\begin{array}{c}92.4 \pm 4.8^{c} \\
(45)\end{array}$ & $\begin{array}{c}105.8 \pm 3.2^{b} \\
(49)\end{array}$ & $\begin{array}{c}129.0 \pm 2.9^{b} \\
(40)\end{array}$ & $\begin{array}{c}139.0 \pm 4.1^{\mathrm{b}} \\
(28)\end{array}$ \\
\hline $\begin{array}{l}\text { Defined IVP } \\
(n)\end{array}$ & - & - & $\begin{array}{c}9.7 \pm 0.3^{b} \\
(40)\end{array}$ & $\begin{array}{c}17.9 \pm 0.6^{b} \\
(39)\end{array}$ & $\begin{array}{c}67.2 \pm 2.5^{c} \\
(20)\end{array}$ & $\begin{array}{c}97.6 \pm 4.9^{b} \\
(29)\end{array}$ & $\begin{array}{c}108.7 \pm 3.4^{b} \\
(33)\end{array}$ & $\begin{array}{c}132.0 \pm 3.3^{b} \\
(30)\end{array}$ & $\begin{array}{c}144.3 \pm 4.5^{b} \\
(18)\end{array}$ \\
\hline $\begin{array}{l}\text { Standard IVP } \\
\text { (n) }\end{array}$ & + & + & $\begin{array}{c}9.2 \pm 0.3^{b} \\
(41)\end{array}$ & $\begin{array}{c}16.6 \pm 0.6^{c} \\
(40)\end{array}$ & $\begin{array}{c}54.7 \pm 2.4^{b} \\
(29)\end{array}$ & $\begin{array}{c}86.6 \pm 5.0^{\mathrm{a}} \\
(19)\end{array}$ & $\begin{array}{c}94.1 \pm 3.8^{\mathrm{a}} \\
(19)\end{array}$ & $\begin{array}{c}107.5 \pm 3.1^{\mathrm{a}} \\
(38)\end{array}$ & $\begin{array}{c}118.1 \pm 4.4^{\mathrm{a}} \\
(24)\end{array}$ \\
\hline$P$ values & & & $<0.01$ & $<0.01$ & $<0.01$ & $<0.01$ & $<0.01$ & $<0.01$ & $<0.01$ \\
\hline
\end{tabular}

Results are least squares means \pm SEM ( $n=$ number of embryos).

*A substantial proportion of morphologically good quality defined IVP (in vitro production) early blastocysts had not yet started expansion at the end of culture at day 8 after insemination.

Effect of treatment on cell cycle duration calculated by Mixed Procedure, model $y=$ treatment, random variable $=$ trial.

abcDifferent superscripts within a column indicate significant differences between individual treatments.

been described previously (van Langendonckt et al., 1997; van Soom et al., 1997; Holm et al., 1998; Lonergan et al., 1999). Chromosomal aberrations in early in vitro-derived bovine embryos are one cause of retarded early embryonic development (Kawarsky et al., 1996; Viuff et al., 2000). These aberrations are frequent, particularly in in vitrocompared with in vivo-derived embryos (Viuff et al., 1999). Aberrant maternal inherited cytoplasm may also interfere with cell cycle kinetics, thus offering a possible explanation for the different kinetics of the viable and non-viable zygotes.

The results of the present study show that maturation and fertilization of bovine oocytes in vivo compared with in vitro influenced subsequent in vitro development of the zygotes. Firstly, in vivo-derived zygotes were more developmentally competent in vitro than were all groups of in vitroderived zygotes, as $87 \%$ versus $\leqslant 54 \%$ of the respective zygotes developed to the compact morula or blastocyst stages. Secondly, the duration of the first cell cycles before the major genomic transition were shorter in in vivo-derived zygotes than in in vitro-derived zygotes (second, third and fifth cell cycles; the first cell cycle was not analysed). Thirdly, the average diameter of in vivo-derived zygotes at hatching was smaller than that of in vitro-produced zygotes.

Increased developmental competence is one of numerous characteristics that differentiates in vivo-derived zygotes from in vitro-derived zygotes (for a review, see Holm and Callesen, 1998) and was also observed by van Soom and de Kruif (1992). Whether the increased competence is caused solely by superior maturation or is a combination of maturation and fertilization in vivo has not been clarified properly. However, in vivo-matured oocytes are more developmentally competent than in vitro-matured oocytes (Greve et al.,
1987; Leibfried-Rutledge et al., 1987; Thompson et al., 1998; P. Humblot, P. Lonergan and P. Holm, unpublished) and cytoplasmic modifications in the germinal vesicle stage oocyte during the growth and dominance phase of the follicle before the LH surge are probably key elements in this difference (Blondin et al., 1997; Hyttel et al., 1997; van de Leemput et al., 1999; Hendriksen et al., 2000). Niemann and Wrenzycki (2000) reported perturbations in the mRNA expression of certain growth factors in in vitro-derived compared with in vivo-derived zygotes. Furthermore, recent studies have shown a relationship between the developmental capacity of oocytes pre-matured/matured in vivo versus in vitro-matured oocytes from an abattoir and the presence of chromosomal aberrations in the respective embryos at day 3 after fertilization (Hendriksen et al., 2001). Hence, it is likely that the observed differences in the duration of the first embryonic cell cycles of in vivo- versus in vitro-derived zygotes is a consequence of such cytoplasmic differences inherited from the mature oocyte and an increased ratio of chromosomal abnormalities.

The fourth cell cycle, which corresponds to the so-called lag phase (Grisart et al., 1994; Holm et al., 1998), differed between in vivo- and in vitro-derived zygotes matured in the absence of serum ( $45 \pm 6$ versus $49 \pm 10 \mathrm{~h}$, respectively; $P<0.01)$. The presence of serum during maturation eliminated this difference, which confirms the significance of the maturation conditions on later development and illustrates the multiplicity of maternally dependent events during the earliest cleavage stages.

The first cell cycle after the major genomic transition, this being the fifth cell cycle from the nine- to the 16-cell stage, was also shorter in in vivo-derived zygotes than in similarly cultured in vitro-derived zygotes. This finding indicates that 
Table 4. Sizes of compact morulae and blastocysts and number of collapses in blastocysts developed in vitro from in vivo zygotes (in vivo) or in vitro in the presence of serum (standard IVP), in chemically defined medium without serum proteins (defined IVP) or in the presence of serum during in vitro maturation and fertilization (IVM-IVF), but in chemically defined in vitro culture (defined IVC)

\begin{tabular}{|c|c|c|c|c|c|}
\hline \multirow[b]{2}{*}{ Treatment } & \multicolumn{2}{|c|}{$\begin{array}{l}\text { Presence of serum } \\
\text { or serum proteins }\end{array}$} & \multirow{2}{*}{$\begin{array}{c}\text { Late morula } \\
\text { area at maximal } \\
\text { compaction }\left(\mu \mathrm{m}^{2}\right)^{*}\end{array}$} & \multirow{2}{*}{$\begin{array}{l}\text { Blastocyst diameter } \\
\text { at hatching }(\mu \mathrm{m})\end{array}$} & \multirow{2}{*}{$\begin{array}{c}\text { Number of collapses } \\
\text { of blastocyst cavity } \\
\text { until hatching }^{+}\end{array}$} \\
\hline & IVM-IVF & IVC & & & \\
\hline In vivo $(n)$ & In vivo $(+)$ & - & $8978 \pm 234^{a}(56)$ & $201 \pm 4^{\mathrm{a}}(43)$ & $5.9 \pm 0.8^{b}(46)$ \\
\hline Defined IVC (n) & + & - & $8559 \pm 262^{\mathrm{a}}(47)$ & $221 \pm 4^{b}(13)$ & $7.0 \pm 0.9^{b}(24)$ \\
\hline Defined IVP $(n)$ & - & - & $8764 \pm 311^{a}(29)$ & $222 \pm 6^{b}(11)$ & $10.0 \pm 1.4^{\mathrm{a}}(12)$ \\
\hline Standard IVP $(n)$ & + & + & $9806 \pm 378^{b}(18)$ & $217 \pm 6^{b}(14)$ & $7.9 \pm 1.5^{\mathrm{ab}}(10)$ \\
\hline$P$ value & & & $<0.01$ & $<0.01$ & $\leqslant 0.03$ \\
\hline
\end{tabular}

Results are least squares means $\pm \operatorname{SEM}(n=$ number of embryos).

IVP: in vitro production.

*The area of the late morula was calculated by Microvision ${ }^{\mathrm{TM}}$ software on the basis of the number of pixels within the circumference of its image. The areas of late morulae in which a larger part of the blastomeres (one-half, one-third or one-quarter) had degenerated during earlier cell cycles were adjusted before statistical analysis by dividing the measured area by $0.5,0.67$ or 0.75 , respectively.

${ }^{+}$A collapse was defined as any reduction in size (small or large) of the blastocoel.

Effect of treatment on cell cycle duration was calculated by Mixed Procedure, model $y=$ treatment, random variable $=$ trial.

${ }^{a b}$ Different superscripts within a column designate significant differences between individual treatments.

maternal cytoplasmic factors influencing the cell cycle may still be pertinent or that the genomic transition as such is perturbed in in vitro-derived zygotes and, thus, may influence the subsequent cell cycle. However, the times of compaction, blastulation or hatching did not differ between in vivo- and in vitro-derived zygotes cultured under similar conditions. This finding indicates that the parts of the embryonic genome that regulate these events are able to function normally under in vitro culture conditions. Recent studies of the expression of specific genes involved in compaction, blastulation and metabolism of bovine embryos have led to a similar suggestion, as no differences were found between blastocysts derived from in vivoversus in vitro-matured oocytes (Knijn et al., 2001).

No differences in the kinetics or time of compaction and blastulation between in vivo- and in vitro-derived zygotes cultured in defined, serum-free medium were observed. However, the average diameter of the zonae pellucidae of in vivo-derived zygotes was significantly smaller $(201 \mu \mathrm{m}$ versus $217-221 \mu \mathrm{m})$. The zonae pellucidae of in vivoderived zygotes differ from those of in vitro-derived zygotes in structure with respect to the exposure and coating of oviductal glycoproteins (Wegner and Killian, 1991) and resistance to proteases (Pollard and Leibo, 1993). Recently, Katska et al. (1999) demonstrated a relationship between exposure to oviductal glycoproteins and high protease resistance by exposing in vitro-matured oocytes to oviductal fluid and subsequently measuring the resistance of their zonae pellucidae to proteases. Even very short exposure of in vitro-matured oocytes to oviductal fluid produced high resistance similar to that observed in in vivo-derived zygotes. It is possible that the smaller hatching diameter of the in vivo-derived zygotes found in the present study is also a consequence of exposure to oviductal fluid causing a more rigid or less elastic zona pellucida, which cracks at a smaller diameter. However, the possibility that the in vivoderived bovine blastocysts secrete substances that directly affect the properties of the zona pellucida, as seen in hamsters, cannot be eliminated (Gonzales and Bavister, 1995; Mishra and Seshagiri, 1998). However, when in vivoderived hamster blastocysts were cultured in vitro, the lysis of zonae pellucidae apparently correlated to the presence of albumin in the culture medium (Mishra and Seshagiri, 1998), whereas, in the present study, in vivo-derived zygotes were cultured in defined conditions.

The absence of serum during maturation and fertilization significantly increased the duration of the first and fourth cell cycles by 4-5 h. Holm et al. (1999) reported that maturation and fertilization of bovine oocytes under defined conditions resulted in lower cleavage, as well as lower developmental capacity of the zygotes, without affecting nuclear maturation. Eckert and Niemann (1995) reported that serum proteins were required for normal pronucleus formation but not for cleavage and subsequent embryo development, which could explain the prolonged first cell cycle of in vitro-derived zygotes matured in the absence of serum proteins. However, in a recent study looking at the kinetics of the second meiotic division (P. Holm, M. D. Madsen, P. J. Booth and H. Callesen, unpublished), sperm penetration in the absence of serum during both maturation and fertilization was delayed by about $4 \mathrm{~h}$ compared with fertilization in the presence of serum, thereby providing a likely explanation for the observed prolongation of the first cell cycle. However, the prolongation of the fourth cell cycle accommodating the major genomic transition indicates that there may be underlying cytoplasmic deficiencies related to suboptimal IVM-IVF under the defined, serumfree conditions. 
Neither the kinetics of compaction nor the time of blastulation differed between in vitro zygotes matured and fertilized with or without serum. Blastocysts matured and fertilized without serum tended to collapse and re-expand more times before hatching, indicating a higher degree of dysfunction in the trophoblast cells of such embryos.

Serum accelerates preimplantation development of bovine embryos (Pinyopummintr and Bavister, 1994; van Langendonckt et al., 1997; Yoshioka et al., 1997; Thompson et al., 1998). It also can have a biphasic action during in vitro culture, suppressing precompaction embryo development but enhancing blastocyst development (Pinyopummintr and Bavister, 1994); thus, addition of serum to the culture medium after the eight-cell stage can increase blastocyst development and quality (Thompson et al., 1998).

It is generally accepted that the ability of serum to support embryo development differs significantly between types and batches. In the present study, the specific batch of serum had been preselected for its overall ability to support blastocyst development.

No influence of serum on the duration of the cell cycle of the first cleavage was observed in the present study, but early blastocysts were generally observed about 16-18 h earlier under serum conditions compared with serum-free conditions. The duration of the fourth cell cycle, in which the maternal-embryonic genomic transition occurs, was shortened significantly, as was the interval from the early to compact morula stage, during which time the first trophoblast cell differentiation is observed (Ducibella et al., 1975). Finally, the duration of the interval from the compact morula to the early blastocyst stage was significantly shortened as a result of premature blastulation. These observations are in full agreement with those of van Langendonckt et al. (1997). Serum contains an abundance of potential peptide growth factors, of which several improve in vitro development to the blastocyst stage and are present as ligands or receptors in the genital tract and preimplantation embryos (Kane et al., 1997). The culture medium in general and serum specifically exert a substantial influence on the expression of genes in early preimplantation embryos, including genes involved in compaction and blastulation (Niemann and Wrenzycki, 2000). Specific differences in mRNA expression have been observed from the fourth cell cycle onwards between embryos cultured in the presence and absence of serum (Wrenzycki et al., 1999).

In vitro-produced compact morulae and blastocysts deviate ultrastructurally from those produced in vivo, irrespective of the presence or absence of serum in the culture medium (Crosier et al., 2000, 2001), but the presence of serum during culture adds to the deviation with respect to some cellular ultrastructures (Gardner, 1994; Abe et al., 1999; Crosier et al., 2000, 2001). In the present study, the most striking morphological characteristic of premature blastulation was poor compaction of morulae; a feature that has also been noticed when comparing in vivo and in vitro morulae cultured in medium supplemented with serum (van Soom and de Kruif, 1992). In the present study, the accel- erated blastocyst formation was accompanied by a $10 \%$ increase in the projected area of the cell mass of the morulae at maximal compaction. This may reflect an increased embryo volume due to early extracellular fluid accumulation between the relatively large blastomeres of the early morulae. Serum-induced premature blastulation is not accompanied by cell proliferation (Yoshioka et al., 1997; Thompson et al., 1998) and the present study showed that serum supplementation did not alter the speed or quality of blastocoel expansion. This finding indicates that the effect of serum may be linked to the cell biological processes initiating blastocoel formation within the fifth cell cycle of the bovine embryo rather than to the mechanisms involved in blastocoel expansion.

The present study has illustrated differences and similarities in the developmental kinetics of bovine in vivo- and in vitro-derived zygotes under different culture conditions. In general, the in vitro developmental capability of bovine zygotes was reflected in the duration of their first cell cycles. In addition, the time-lapse system permitted a description of the general patterns of embryo attrition and blastomere degeneration until the morula stage. From these analyses it can be concluded that development of most of the nonviable embryos was blocked in the second and fourth cell cycles, as two-cell and five- to eight-cell embryos, but also that a large proportion of activated in vitro-derived oocytes did not cleave at all. Moreover, blastomere degeneration was observed in all cell cycles until the morula stages, but most often at the third and fourth cell cycles of the viable embryos. Furthermore, it is concluded that, in general, viable in vivo-derived zygotes develop faster through the first cell cycles than do in vitro-derived zygotes. However, serum supplementation during both maturation and culture was able to modify developmental kinetics significantly, thus highlighting the need to be cautious when comparing in vivo- and in vitro-derived embryos. The absence of serum during IVM-IVF increased the duration of the first cell cycle, presumably as a result of compromised sperm penetration and, also, increased the duration of the fourth cell cycle, during which the major genome transition takes place. In contrast, serum supplementation during culture significantly decreased the duration of the fourth cell cycle and, furthermore, impaired compaction and induced premature blastulation by decreasing the time between the early morula, compact morula and early blastocyst stages without parallel cell proliferation.

The authors would like to thank Anette Pedersen and Klaus Villemoes for their technical assistance. This work was supported in part by a European Commission grant (QLK3-CT1999-00104) and in part via the research project 'Reproduction technologies in animal breeding' (FREM98-8) financed by the Danish Directorate for Development.

\section{References}

Abe H, Yamashita Y, Itoh T, Satoh T and Hoshi H (1999) Ultrastructure of bovine embryos developed from in vitro-matured and -fertilised 
oocytes: comparative morphological evaluation of embryos cultured either in serum-free medium or in serum-supplemented medium Molecular Reproduction and Development 53 325-335

Blondin P, Coenen K, Guilbault LA and Sirard MA (1997) In vitro production of bovine embryos: developmental competence is acquired before maturation Theriogenology 47 1061-1075

Crosier E, Farin PW, Dykstra MJ, Alexander JE and Farin CE (2000) Ultrastructural morphometry of bovine compact morulae produced in vivo or in vitro. Biology of Reproduction 62 1459-1465

Crosier E, Farin PW, Dykstra MJ, Alexander JE and Farin CE (2001) Ultrastructural morphometry of bovine blastocysts produced in vivo or in vitro. Biology of Reproduction 64 1375-1385

Ducibella T, Albertini DF, Anderson E and Biggers JD (1975) The preimplantation mammalian embryo: characterization of intercellular junctions and their appearance during development Developmental Biology 45 231-250

Eckert J and Niemann H (1995) In vitro maturation, fertilization and culture to blastocysts of bovine oocytes in protein-free media Theriogenology 43 1211-1225

Galli C and Lazzari G (1996) Practical aspects of IVM/IVF in cattle Animal Reproduction Science 42 371-379

Gardner DK (1994) Mammalian embryo culture in the absence or presence of serum or somatic cell support Cell Biology International 18 1163-1179

Gonzales DS and Bavister BD (1995) Zona pellucida escape by hamster blastocysts in vitro is delayed and morphologically different compared with zona escape in vivo. Biology of Reproduction 52 470-480

Greve T, Xu KP, Callesen H and Hyttel P (1987) In vivo development of in vitro fertilized bovine oocytes matured in vivo versus in vitro. Journal of In Vitro Fertilisation and Embryo Transfer 4 281-285

Grisart B, Massip A and Dessy F (1994) Cinematographic analysis of bovine embryo development in serum-free oviduct-conditioned medium Journal of Reproduction and Fertility 101 257-264

Hasler JF, Henderson WN, Hurtgen PJ et al. (1995) Production, freezing and transfer of bovine IVF embryos and subsequent calving results Theriogenology 43 141-152

Hendriksen PJM, Vos PLAM, Steeweg WNM, Bevers MM and Dieleman SJ (2000) Bovine follicular development and its effect on the in vitro competence of oocytes Theriogenology 53 11-20

Hendriksen PJM, Viuff D, Greve T, Vos PLAM, Mullart E, Bevers MM and Dieleman SJ (2001) Effect of the origin of bovine oocytes on cell numbers and numerical chromosome aberrations in in vitro embryos collected at day 3 post-insemination Theriogenology 55475 (Abstract)

Holm P and Callesen H (1998) In vivo versus in vitro produced bovine ova: similarities and differences relevant for practical application Reproduction, Nutrition and Development 38 579-594

Holm P, Walker SK and Seamark RF (1996) Embryo viability, duration of gestation and birth weight in sheep after transfer of in vitro matured and in vitro fertilized zygotes cultured in vitro or in vivo. Journal of Reproduction and Fertility 107 175-181

Holm P, Shukri NN, Vajta G, Booth P, Bendixen C and Callesen H (1998) Developmental kinetics of the first cell cycles of bovine in vitro produced embryos in relation to their in vitro viability and sex Theriogenology 50 1285-1299

Holm P, Booth PJ, Schmidt MH, Greve T and Callesen H (1999) High bovine blastocyst development in a static in vitro production system using SOFaa medium supplemented with sodium citrate and myoinositol with or without serum-proteins Theriogenology 52 683-700

Hyttel P, Fair T, Callesen H and Greve T (1997) Oocyte growth, capacitation and final maturation in cattle Theriogenology 47 23-32

Kane MT, Morgan PM and Coonan C (1997) Peptide growth factors and preimplantation development Human Reproduction Update 3 137-157

Katska L, Kania G, Smorag Z, Wayda E and Plucienniczak G (1999) Developmental capacity of bovine IVM/IVF oocytes with experimentally induced hardening of the zona pellucida Reproduction in Domestic Animals 34 255-259

Kawarsky SJ, Basur PK, Stubbings RB, Hansen PJ and King WA (1996) Chromosomal abnormalities in bovine embryos and their influence on development Biology of Reproduction 54 53-59
Knijn HM, Wrenzycki C, Hendriksen PJM, Vos PLAM, van der Weijden GC, Niemann H and Dieleman SJ (2001) Effects of in vitro versus in vivo maturation on gene expression in single bovine blastocysts Theriogenology 55238 (Abstract)

Leibfried-Rutledge ML, Critser ES, Eyestone WH, Northey DL and First NL (1987) Development potential of bovine oocytes matured in vitro or in vivo. Biology of Reproduction 36 376-383

Lindner GM and Wright RW (1983) Bovine embryo morphology and evaluation Theriogenology 20 407-416

Lonergan P, Khatir H, Piumi F, Rieger D, Humblot P and Boland MP (1999) Effect of time interval from insemination to first cleavage on the developmental characteristics, sex ratio and pregnancy rate after transfer of bovine embryos Journal of Reproduction and Fertility 117 159-167

Marquant-Le Guienne B, Guyader-Joly C, Ponchon S, Delalleau N, Florin B, Ede P, Ponsart C, Guerin B and Humblot P (2001) Results of in vitro production in a commercial ovum pick-up program Theriogenology $\mathbf{5 5}$ 433 (Abstract)

Merton S (1997) Project HGEP5: in vitro production of bovine embryos after ovum pick-up Holland Genetics Research report October 1996-March 1997

Mishra A and Seshagiri PB (1998) Successful development in vitro of hamster 8-cell embryos to 'zona-escaped' and attached blastocysts: assessment of quality and trophoblast outgrowth Reproduction, Fertility and Development 10 413-420

Niemann H and Wrenzycki C (2000) Alterations of expression of developmentally important genes in preimplantation bovine embryos by in vitro culture conditions Theriogenology 53 21-34

Peippo J, Kurkilahti M and Bredbacka P (2001) Developmental kinetics of in vitro produced bovine embryos: the effect of sex, glucose and exposure to time-lapse environment Zygote 9 105-113

Pinyopummintr T and Bavister BD (1994) Development of bovine embryos in a cell-free culture medium: effects of type of serum, timing of its inclusion and heat inactivation Theriogenology 41 1241-1249

Pollard JW and Leibo SP (1993) Comparative cryobiology of in vitro and in vivo derived bovine embryos Theriogenology 39287 (Abstract)

SAS Institute Inc. (1992) The mixed procedure. In SAS ${ }^{\circledR}$ Technical Report $P$-229. Release 6.07 pp 287-406. Cary, NC

SAS Institute Inc. (1993) The Genmod procedure. In $S A S^{\circledR}$ Technical Report $P$-243. SAS/STAT Software, Release 6.09 pp 88. Cary, NC

Thompson JG (1997) Comparison between in vivo-derived and in vitroproduced pre-elongation embryos from domestic ruminants Reproduction, Fertility and Development 9 341-354

Thompson JG, Allen NW, McGowan LT, Bell ACS, Lambert MG and Tervit HR (1998) Effect of delayed supplementation of fetal calf serum to culture medium on bovine embryo development in vitro and following transfer Theriogenology 41 1239-1249

van de Leemput EE, Vos PL, Zeinstra EC, Bevers MM, van der Weijden GC and Dieleman SJ (1999) Improved in vitro embryo development using in vivo matured oocytes from heifers superovulated with a controlled preovulatory LH surge Theriogenology 52 335-349

van Langendonckt A, Donnay I, Schuurbiers N, Auquier P, Carolan C, Massip A and Dessy F (1997) Effects of supplementation with fetal calf serum on development of bovine embryos in synthetic oviduct fluid medium Journal of Reproduction and Fertility 109 87-93

van Soom A and de Kruif A (1992) A comparative study of in vivo and in vitro derived bovine embryos $12^{\text {th }}$ International Congress of Animal Reproduction and Artificial Insemination 3 1365-1367

van Soom A, Ysebaert MT and de Kruif A (1997) Relationship between timing of development, morula morphology, and cell allocation to inner cell mass and trophectoderm in in vitro-produced bovine embryos Molecular Reproduction and Development 47 47-56

van Wagtendonk-de Leeuw AM, Mullaart E, de Roos APW, Merton JS, den Daas JHG, Kemp B and de Ruigh L (2000) Effects of different reproduction techniques: $\mathrm{Al}, \mathrm{MOET}$ or IVP on health and welfare of bovine offspring Theriogenology 53 575-597

Viuff D, Rickords L, Offenberg H et al. (1999) A high proportion of bovine blastocysts produced in vitro are mixoploid Biology of Reproduction $\mathbf{6 0}$ 1273-1278

Viuff D, Greve T, Avery B, Hyttel P, Brockhoff PB and Thomsen PD (2000) 
Chromosome aberrations in in vitro-produced bovine embryos at days 2-5 post-insemination Biology of Reproduction 63 1143-1148

Watanabe YF, Dayan A, Meirelles FV and Watanabe MR (2001) Pre and post implantation development of IVP bovine embryos Theriogenology 55441 (Abstract)

Wegner CC and Killian GJ (1991) In vitro and in vivo association of an oviduct estrus-associated protein with bovine zona pellucida Molecular Reproduction and Development 29 77-84

Wrenzycki C, Herrmann D, Carnwath JW and Niemann H (1999) Alterations in the relative abundance of gene transcripts in preimplantation bovine embryo culture in medium supplemented with either serum or PVA Molecular Reproduction and Development 53 8-18

Yoshioka K, Othman AM, Taniguchi T, Yamanaka H and Sekikawa K (1997)
Differential patterns of blastulation in bovine morulae cultured in synthetic oviduct fluid medium containing FCS or BSA Theriogenology 48 997-1008

Yoshioka K, Suzuki C and Iwamura S (2000) Effects of activin A and follistatin on developmental kinetics of bovine embryos: cinematographic analysis in a chemically defined medium Journal of Reproduction and Fertility 118 119-125

Received 2 August 2001.

First decision 1 October 2001.

Revised manuscript received 28 December 2001.

Accepted 2 January 2002. 